\title{
DETERMINANTS OF BREAST SELF-EXAMINATION (BSE) ONCE A MONTH REGULARLY IN WOMEN OF CHILDBEARING AGE IN KUBUTAMBAHANAN VILLAGE Ari Pertama Watiningsih ${ }^{1}$, Desak Ketut Sugiartini ${ }^{2 *}$ \\ ${ }^{1}$ Program Studi DIII Kebidanan, Sekolah Tinggi Ilmu Kesehatan Buleleng \\ ${ }^{2}$ Program Studi DIII Kebidanan, Sekolah Tinggi Ilmu Kesehatan Buleleng \\ *E-mail : desakketutsugiartini@gmail.com
}

\begin{abstract}
Significant condition occurred in increased rate of breast cancer, based on global statistical data. Awareness of breast cancer prevention methods is very important in reducing morbidity and mortality caused by breast cancer. One of them with breast self-examination (BSE) because it is easy, cheap, privacy, safe and does not require special equipment, but this method is not yet widely applied by most women. The purpose of this study was to determine the determinants of regular breast self-examination once a month by women of childbearing age in the Kubutambahanan Village. The method of research was observational with cross sectional approach. Samples were taken purposively with a large number of samples determined as many as 154 respondents. The independent variables were age, level of education, occupation, family history of breast cancer, distance of health facility coverage, mass media exposure, partner / family support, peer group support, dependent variable in this study was breast self-examination behavior. Data collection using questionnaires with structured interview techniques. The study began in June until September 2019. The results of this study found that the determinant variable of monthly breast self-examination was education level ( $\mathrm{OR}=5,321.95 \% \mathrm{CI}$ : $-0.324--0.213)$, mass media access $(\mathrm{OR}=$ 3,543.95\% CI: $-0.213-0.124)$, partner or family support (OR $=7,002.95 \%$ CI: $-1.342-0.543)$ and peer age group support $(\mathrm{OR}=5,326.95 \% \mathrm{CI}$ : $-3.234-1.342)$ remain jointly influential for regular monthly breast self examination. Breast self-examination every month is regularly related to factors of education level, mass media access, partner or family support and peer support.
\end{abstract}

Keywords: Breast Self Examination, Fertile Age Women, Women of Childbearing, Breast Cancer, Determinants of Breast Self Examination

\section{INTRODUCTION}

Cancer is still a non-communicable disease which accounts for the largest mortality rate in the world. Breast cancer as one of the most common cancers in women in developing even in developed countries ${ }^{1}$. A significant condition occurred in the increased rate of breast cancer based on global statistical data ${ }^{2}$. Worldwide, more than 1.15 million people are diagnosed with breast cancer each year and as many as 502,000 women die from this disease each year. This data shows breast cancer as the second largest cause of death in women after lung cancer ${ }^{1}$. In some countries in Africa, the incidence of breast cancer has increased significantly, which is 5\% every year. In Asian the mortality rate of breast cancer shows more than $50 \%$ of deaths in sufferers ${ }^{3}$. In Indonesia, breast cancer is the highest type of cancer in outpatients and inpatients, 
reaching 12,014 people or around $28.7 \%$. The incidence of breast cancer in Indonesia reaches 0.5 per 1000 women, while for Bali Province the prevalence of breast cancer reaches 0.6 per 1000 women ${ }^{4}$. The danger of breast cancer and its development tends to be more aggressive in women of childbearing age. Women aged 20-29 years who are diagnosed with breast cancer have a $72.4 \%$ mortality rate ${ }^{5}$.

Awareness of breast cancer prevention methods is very important in reducing morbidity and mortality caused by breast cancer. Lack of attention to the screening methods for risk factors and cultural influences, many women, especially in developing countries, are embarrassed to declare problems with their breasts, causing late early detection of breast cancer ${ }^{6}$. Early detection of breast cancer will provide a more effective treatment effect and increase the chances of life expectancy in sufferers. Breast cancer detection consists of breast self-examination, clinical breast examination and mammography. One of the three examinations that can be recommended is breast self-examination (aware) because it is easy, cheap, privacy, safe and does not require special equipment ${ }^{1}$. Breast self-examination is very safe to do alone by women at home, and is the most effective screening technique for early detection of breast cancer which only takes approximately 5 minutes ${ }^{7}$.

Although breast self-examination is an early detection technique that is quite cheap and easy to do, this method is not yet widely applied by most women. In one study mentioned only $17 \%$ and $12 \%$ of women do regular breast self-examination every month ${ }^{1}$. Several factors are still an effect of the implementation of breast self-examination. Most women still rule out the effectiveness of regular breast self-examination as a technique for early detection of breast cancer.

Some efforts have been made to increase awareness of women of childbearing age to conduct breast self-examinations such as health education by the nearest Puskesmas (Primary Health Care), but this is not enough to be able to increase awareness and behavior of breast selfexamination regularly in women of childbearing age. One of the determinants of a person doing breast self-examination is the understanding related to the benefits of breast self-examination obtained from the information media accessed ${ }^{8}$. In a preliminary study conducted, found 10 out of 15 women of childbearing age in the Kubutambahanan Village Area said they did not understand the technique of breast self-examination and never did breast self-examination once a month on a regular basis. Moving on from these conditions it is deemed necessary to know the determinants of the implementation of breast self-examination once a month on a regular basis by women of childbearing age in the District of Kubutambahan, so that in the future it is expected to take a real action, which can be taken by the health service and related parties to overcome these conditions so that efforts to prevent death from breast cancer can be suppressed. 


\section{MATERIAL AND METHOD}

In this observational study with a cross sectional approach starting from June 2019 until the end of September 2019, Fertile Age Women were randomly selected in Kubutambahan Village. This village is located in the Kubutambahan village to the east of Buleleng Regency, approximately 15 Kilometers to the east side of the Singaraja City Center. The study population was women of childbearing age in Kubutambahan village. The samples in the study were selected purposively according to the criteria of women who could read and write, women of childbearing age who were not pregnant and breastfeeding, women of childbearing age who were willing to be respondents, had never had breast cancer, and women of childbearing age who lived every day settled in Kubutambahan added village.

The number of samples obtained in this study were 154 people. The data is obtained through primary data, namely direct interview to pick up the ball to the respondent's residence address and secondary data study obtained by researchers through the documentation study of the Puskesmas in the Kubutambahan village, namely the Kubutambahan I Primary Health Care, and information on the environment leader in the Kubutambahan village area. The questionnaire was used in this research in the process of collecting data. The questionnaire consisted of 2 parts. The first part is designed to collect information related to respondents, sociodemography characteristics. The questionnaire was developed by researchers based on a literature review. The second part of the questionnaire consisted of several statements consisting of 2 choices of answers on a Guttman scale. Before data collection began, an agreement to begin data collection was carried out by the researcher with each respondent. Respondents were given information related to the purpose of the study, the rights of respondents during the study. Respondents were given information that any information provided would be kept confidential. on each statement.

The independent variables in this study were age, level of education, occupation, family history of breast cancer, distance of health facility coverage, mass media exposure, partner / family support, peer group support, dependent variable in this study was breast self-examination behavior. Descriptive analysis and bivariate Rank Spearman hypothesis testing and multivariate multiple logistic regression analysis were carried out to determine the independent variables that jointly influence breast self-examination and the chances of women of childbearing age to do or not do breast self-examination regularly once a month. The level of statistical significance is $p$ $<0.05$. 


\section{Result}

\section{RESULTS AND DISCUSSION}

Of the total 154 respondents of childbearing age in Kubutambahan Village all respondents agreed and answered the questionnaire in full.

Table 1. Characteristics of sociodemography, independent variables and dependent variables in women of childbearing age in Kubutambahan Village

\begin{tabular}{|c|c|c|c|}
\hline \multirow[b]{2}{*}{ No. } & \multirow[b]{2}{*}{ Characteristics of Respondents } & \multicolumn{2}{|c|}{ Number of } \\
\hline & & Frequencies (f) & $\begin{array}{c}\text { Percentage } \\
(\%)\end{array}$ \\
\hline \multirow[t]{5}{*}{1.} & Age & & \\
\hline & $21-25$ years & 40 & 25.98 \\
\hline & 26-30 years & 54 & 35.06 \\
\hline & $31-35$ years & 32 & 20.78 \\
\hline & $>35$ years & 28 & 18.18 \\
\hline \multirow[t]{4}{*}{2.} & Marital Status & & \\
\hline & Unmarried & 25 & 16.23 \\
\hline & Married & 127 & 82.47 \\
\hline & Divorced & 2 & 1.30 \\
\hline \multirow[t]{6}{*}{3.} & Education & & \\
\hline & School & 2 & 1.30 \\
\hline & Completion of Primary School & 3 & 1.94 \\
\hline & Completion of Middle School & 15 & 9.74 \\
\hline & Completion of High School & 98 & 63.64 \\
\hline & Completion of College & 36 & 23.38 \\
\hline \multirow[t]{5}{*}{4.} & Occupation & & \\
\hline & Not working / Housewife & 48 & 31.17 \\
\hline & Self-employed & 23 & 14.93 \\
\hline & Private & 4545 & 29.22 \\
\hline & Civil Servant & 38 & 24.68 \\
\hline \multirow[t]{6}{*}{5.} & Religion & & \\
\hline & Hindu & 136 & 88.31 \\
\hline & Islam & 16 & 10.39 \\
\hline & Buddhism & - & - \\
\hline & Christian & 2 & 1.30 \\
\hline & Confucius / other beliefs & - & - \\
\hline \multirow[t]{3}{*}{6.} & History of breast cancer in families & & \\
\hline & Yes & 35 & 22.73 \\
\hline & No & 119 & 77.27 \\
\hline 7. & $\begin{array}{l}\text { Affordability Distance Health facilities } \\
\text { withResidence }\end{array}$ & & \\
\hline
\end{tabular}




\begin{tabular}{llcc}
\hline & Near(<500 meters) & 85 & 55.19 \\
& Distant (> 500 meter) & 69 & 44.81 \\
\hline 8. & Mass Media Access & & \\
\hline & Yes & 127 & \\
& No & 27 & \\
\hline 9. & Spouse / family support & & \\
\hline & Supported & 68 & 47.15 \\
& Not supported & 86 & 55.85 \\
\hline 10. & Supported peer / environment age groups & \\
\hline & Supported & & 29.22 \\
& Not supported & 45 & 70.78 \\
\hline 11. & Regular Breast Examination a month s ekali & 109 & \\
\hline & Yes & & 22.72 \\
& No & 35 & 77.28 \\
\hline
\end{tabular}

Table 1 shows the distribution of respondents based on demographic characteristics and characteristics of the independent and dependent variables. Overall, the majority of people were in the range of 26-30 years, namely 54 people $(35.06 \%)$, the marital status of the majority married 127 people (82.47\%). Most of the respondents graduated from high school, namely 98 people $(63.64 \%)$ with the majority of the work status being unemployed / housewives, 48 people $(31.17 \%)$. Viewed from religion, the majority of Hindu respondents were 136 people $(88.31 \%)$. The results of a descriptive analysis of the history of breast cancer in the family showed that most of the results stated that they did not have a history of 119 people (77.27\%). Judging from the affordability of the distance of health facilities from where to live, the majority of 85 people (55.19\%) stated that they were close to the Puskesmas. Furthermore, in the mass media access and partner / family support in a row the majority, 127 people $(82.47 \%$ ) stated that they can access the mass media related to breast examination and 86 people $(55.85 \%)$ do not have the support of spouse / family to do a breast examination once a month. regularly. In the majority age group support / environment namely 109 people (70.78\%) did not get support. Of the total respondents, namely 119 people (77.28\%) did not do breast self-examinations once a month on a regular basis.

Table 2. Bivariate Analysis Relationship Between Independent Variables and Regular Breast Self Examination Once a Month in Fertile Age Women in Kubutambahan Village

\begin{tabular}{llcc}
\hline \multirow{2}{*}{ No. } & \multicolumn{1}{c}{ Independent Variable } & $\begin{array}{c}\text { Correlation Coefficient } \\
(\mathbf{r})\end{array}$ & P value \\
\hline 1. & Age & $-2,063$ & 0.083 \\
\hline 2. & Education level & 0.851 & 0,000 \\
\hline 3. & Occupation & 1,021 & 0.092 \\
\hline 4. & Family history of breast cancer & 1,054 & 1,023 \\
\hline 5. & Affordability Distance of Health Facilities to & -2.121 & 0.235 \\
\hline
\end{tabular}




\begin{tabular}{llcc}
\hline & Residence & & \\
\hline 6. & Access Mass Media & 0.673 & 0.035 \\
\hline 7. & Spouse /Family Support & 0.543 & 0.003 \\
\hline 8. & Supported peer / environment age groups & 0.745 & 0.002 \\
\hline
\end{tabular}

Table 3. Multivariate Analysis of Independent Variable Logistic Regression Test with Regular Breast Self Examination Once a Month in Fertile Age Women in Kubutambahanan Village

\begin{tabular}{|c|c|c|c|c|c|c|}
\hline \multirow{2}{*}{$\begin{array}{l}\text { No } \\
\text {. }\end{array}$} & \multirow{2}{*}{ Variable } & \multirow{2}{*}{$\begin{array}{c}\text { Nilai } \\
\mathbf{P}\end{array}$} & \multirow{2}{*}{ OR } & \multicolumn{2}{|c|}{$\begin{array}{l}95 \% \text { Confidence } \\
\text { Interval }\end{array}$} & \multirow{2}{*}{$\begin{array}{c}\mathrm{R} \\
\text { Squa } \\
\text { re }\end{array}$} \\
\hline & & & & $\begin{array}{l}\text { Lower } \\
\text { Bound }\end{array}$ & $\begin{array}{l}\text { Upper } \\
\text { Bound }\end{array}$ & \\
\hline 1. & Age & 0,451 & $-\overline{2}-342$ & -0.231 & 3.012 & $\begin{array}{l}0.53 \\
2\end{array}$ \\
\hline 2. & Education Level & 0,015 & 5.321 & -0.324 & -0.213 & \\
\hline 3. & Occupation & 0,321 & $-\overline{2}$ & & & \\
\hline 4. & Family history of breast cancer & 0,661 & $-\overline{3}-212$ & -2.312 & 1.543 & \\
\hline 5. & $\begin{array}{l}\text { Affordability Distance of Health } \\
\text { Facilities to Residence }\end{array}$ & 0,739 & $-\overline{1}-1.754$ & -4.213 & 0.324 & \\
\hline 6. & Access Mass Media & 0.012 & 3.543 & -0.213 & -0.124 & \\
\hline 7. & Spouse /Family Support & 0.003 & 7.002 & -1.342 & -0.543 & \\
\hline & $\begin{array}{l}\text { Supported peer / environment age } \\
\text { groups }\end{array}$ & 0.025 & 5.326 & -3.234 & -1.342 & \\
\hline
\end{tabular}

Based on the results of a study developed from this research, it is found referring to table 2 related to the results of the analysis of the relationship of each independent variable with the breast examination variable once a month that the education level variable is significantly related to breast examination once a month regularly in women of childbearing age $(\mathrm{p}=0.000, \mathrm{r}=$ 0.851). These results indicate a direct relationship with the strength of the relationship 0.851 which is in the range of a very strong relationship. This unidirectional relationship means that the higher level of education will increase breast self-examination once a month on a regular basis in women of childbearing age. The mass media access variable results show that also significantly related to breast self-examination once a month regularly $(\mathrm{p}=0.035, \mathrm{r}=0.673)$. This means a strong positive relationship between mass media access variables and regular breast examinations once a month. The higher intensity of mass media access by women of childbearing age will increase breast examination once a month on a regular basis. Almost the same on the variable partner / family support and peer support group / environment there is a significant relationship with regular breast examination once a month $(p=0.003, r=0.543),(p=$ $0.002, r=0.745)$. Both of these variables have a strong positive relationship with breast self- 
examination once a month on a regular basis, which means that the higher level of family / peer support and peer age / environmental support will also increase with regular breast examinations once a month on women of childbearing age. The age variable was not significantly related to regular breast examinations once a month in women of childbearing age $(p=0.083, r=-.063)$. In addition to age, occupational variables, family history of breast cancer and the affordability of successive distance from health facilities to residence were not significantly associated with regular monthly breast examinations in women of childbearing age $(\mathrm{p}=0.092, \mathrm{r}=1.021),(\mathrm{p}=$ $1,023, \mathrm{r}=1,054),(\mathrm{p}=0.235, \mathrm{r}=-2.121)$.

Based on the consideration of the literature study, all independent variables are jointly entered into the logistic regression equation and the results obtained are education level variables $(\mathrm{OR}=5,321.95 \% \mathrm{CI}:-0.324--0.213)$, mass media access (OR = 3,543, 95\% CI: -0.213--0.124), spouse / family support $(\mathrm{OR}=7,002.95 \% \mathrm{CI}$ : $-1.342--0.543)$ and peer age group support $(\mathrm{OR}=$ 5,326.95\% CI: -3.234--1.342) still jointly affect the breast examination once a month on a regular basis. It can be seen that each increase of 1 level of education will increase the chances of 5.3 times women of childbearing age in Kubutambahan village to do breast self-examinations once a month regularly. The results of data analysis also showed that each time mass media access would increase the chances of 3.5 times women of childbearing age to do breast selfexaminations once a month regularly. Each partner / family support will increase the chances 7 times of women of childbearing age to do breast self-examinations once a month on a regular basis. Likewise, each peer support group / environment will increase the chances of 5.3 times women of childbearing age to do breast self-examinations once a month on a regular basis in Kubutambahan Village. Age, occupation, family history of breast cancer, and the affordability of the distance of health facilities to a place to live together do not have an influence on breast selfexamination once a month on a regular basis in women of childbearing age in Kubutambahan Village.

\section{Discussion}

Breast cancer is the most common cancer that causes death in women. Late diagnosis and treatment will result in a poor prognosis of this cancer ${ }^{5}$. The results of the literature study assembled the effectiveness of breast self-examination as a method for early detection of breast cancer is still controversial. But based on the results of the recommendations of the American Cancer Society and the Indonesian Ministry of Health continues to encourage women to pay attention to how the condition of the breasts look and feel weird, so that earlier women can consult with doctors. To achieve this goal, women should start thinking about having their own breast checks once a month on a regular basis. Many factors determine the breast examination itself by women of childbearing age.

In this study the variables of education level, mass media access, partner / family support, and peer group support are the factors that determine a woman of childbearing age to do breast selfexamination once a month. This is in accordance with research conducted by Elshamy and 
Shoma ${ }^{9}$ someone will take an action because of knowledge of the consequences that will be obtained. In this study, most of the education level of the respondents were high school graduates, namely 98 people $(63.64 \%)$. These results are consistent with research Obaji, Elom ${ }^{10}$ which states that 127 people $(54.2 \%)$ of women who were respondents in breast examinations were high school level. If seen from the level of education at the high school level an individual can already be said to have a high level of education. The higher the level of education, the understanding of an individual will increase, so that the tendency to take action in an effort to improve the degree of health will be better too ${ }^{11}$. In the research results found an increase in education level will increase 5.3 times the chance of a woman to do breast self-examination once a month regularly. The results of this study were supported by research conducted by Didarloo, Nabilou ${ }^{12}$ who said women with higher levels of education would have 5.51 times the opportunity to do breast self-examination. The level of knowledge can be represented from the level of one's education. The higher the level of one's education it can be said the higher the level of one's knowledge so that understanding of early detection will be better and lead to breast selfexamination once a month on a regular basis.

The results showed that most of the respondents could access the mass media and the influence of the mass media could increase 3 times the chances of women of childbearing age to do breast self-examinations every month on a regular basis. The results of this study are supported by other studies, namely the influence of information obtained from mass media such as television and other digital media can support twice the chance of women of childbearing age to do breast examinations once a month regularly ${ }^{13}$. Through mass media, recipients of information will be open-minded and encourage attitudes related to the information conveyed. So that early breast cancer detection techniques are delivered through mass media, it is hoped that women's understanding will be better ${ }^{14}$. The effectiveness of this information media needs to be improved because the majority only includes a general understanding of breast cancer and prevention efforts, but specific techniques for breast examination need to be added more in the information content provided so that it is more applicable and easier for women of childbearing age to practice.

In addition, partner / family support factors will also affect a woman of childbearing age to do a breast exam. The existence of the family as a provider of support and also as the first health education provider of an individual. From this study it was revealed that the influence of partner / family support would increase the chance 7 times to improve breast self-examination once a month on a regular basis. This is in line with research conducted by Al-Dubai, Ganasegeran ${ }^{15}$ found that family support would increase 3 times breast self-examination regularly. Family support is a reinforcement and the formation of behavior of an individual, where each support and intimacy will cause a relationship to affect each other's behavior patterns ${ }^{16}$. Other research results, namely Barghouti, Yasein ${ }^{17}$ who found that the support of the closest person will increase the chances of a woman twice to do an early breast self-examination. Spouse or family is the closest person who will give a reciprocity to individuals both positive and negative. So if 
the support given by a partner or family to take precautionary measures to improve the degree of health then the individual will be more likely to be able to implement these behaviors ${ }^{18}$. This support will form a motivation for a woman to do breast self-examination regularly. Optimizing the participation of family and partner roles in encouraging women to do breast selfexaminations, by the government and health workers, needs to be improved.

In this study it was found that the majority of respondents did not get support from the age group / peer. This is likely due to the myths that have occurred in the community about breast cancer caused by witchcraft and the perception that holding the breast is taboo ${ }^{11}$. Peer / environmental support groups will shape an individual's behavior. Behavior is the result of individual characteristics and the environment. If the trust and confidence in an object supports the creation of a certain behavior, then the behavior occurs ${ }^{11}$. In this study the results obtained support the peer group / environment will increase the chances of 5.3 times a woman to do breast self-examination regularly a month. These results are consistent with the review literature which says social support including workplaces, family and friends will increase positive attitudes towards preventive health-related efforts. In addition, social support also has an effect on the self-efficacy of an individual to overcome a problem at hand, so it can be said that social support from friends and the environment will form an impetus for breast self-examination ${ }^{19}$.

Family history of breast cancer in this study has not shown a significant effect on breast selfexamination once a month on a regular basis, this can happen is possible because respondents in the study did not have a close attachment between families so that the experience of other family members related to breast cancer does not really affect respodent behavior. Likewise, the distance from the health facility does not show a significant effect on breast self-examination once a month on a regular basis, this is because almost most of the respondents have been able to access health safety facilities such as Puskesmas with private vehicles or public vehicles available so that it does not become determinants of respondents not to do or do breast selfexamination once a month regularly in this study.

The need for the role of the media that not only presents the dangers and benefits of breast self-examination but also the need for the role of the mass media here as an effective means to improve breast self-examination by adding step by step procedures for breast examination itself practically. The policy holders and health workers also need to improve health education at the level of adolescence, especially at the high school level because most of the development of reproductive organs was in the high school period. The need to involve family and community leaders to be able to distribute information related to the importance of breast self-examination because partner / family support and also the environment greatly affect breast self-examination conducted by women, especially suppressing negative myths that spread in the community related to breast cancer and breast examination . 


\section{CONCLUSION}

The results of the study show the practice of breast self-examination once a month on a regular basis, is still quite low and is influenced by factors of education level, mass media access, spouse / family support and support of age groups / environment. Therefore, looking at the conditions mentioned above, interventions are needed to improve the practice of breast selfexamination from related parties such as the Health Office, Puskesmas and chairperson of the environment by taking into account the influential factors above to find a solution to improve breast self-examination regularly.

\section{ACKNOWLEDGEMENT}

Thank you researchers say to the Puskesmas Kubutambahan I who have assisted the research process and also the Head of the Environment in each Banjar Dinas in Kubutambahan Village in providing secondary sources of information related to respondents

\section{REFERENCES}

1. Nde FP, Assob JCN, Kwenti TE, Njunda AL, Tainenbe TRG. Knowledge, attitude and practice of breast self-examination among female undergraduate students in the University of Buea. BMC Research Notes. 2015 2015/02/15;8(1):43.

2. Pradhan SS, Shrestha R, Parajuli P, Khagi RB, Bhandari B. Knowledge, attitude and practice regarding breast self examination among female health personnel. Journal of Kathmandu Medical College. 2017;6(4):156-60.

3. Sangruangake M, Promthet S. Awareness of Breast Cancer and Its Section Screening among Indonesian Women: Universitas Ahmad Dahlan; 2018.

4. Dyanti GAR, Suariyani NLP. Faktor-Faktor Keterlambatan Penderita Kanker Payudara dalam Melakukan Pemeriksaan Awal ke Pelayanan Kesehatan. KEMAS: Jurnal Kesehatan Masyarakat. 2016;11(2):276-84.

5. Akhtari-Zavare M, Juni MH, Said SM, Ismail IZ. Beliefs and behavior of Malaysia undergraduate female students in a public university toward breast self-examination practice. Asian Pacific Journal of Cancer Prevention. 2013;14(1):57-61.

6. Ruddy KJ, Gelber S, Tamimi RM, Schapira L, Come SE, Meyer ME, et al. Breast cancer presentation and diagnostic delays in young women. Cancer. 2014;120(1):20-5.

7. Birhane N, Mamo A, Girma E, Asfaw S. Predictors of breast self-examination among female teachers in Ethiopia using health belief model. Archives of Public Health. 2015;73(1):39.

8. Arafah ABR, Notobroto HB. Faktor Yang Berhubungan Dengan Perilaku Ibu Rumah Tangga Melakukan Pemeriksaan Payudara Sendiri (Sadari). The Indonesian Journal of Public Health. 2018;12(2):143-53.

9. Elshamy KF, Shoma AM. Knowledge and practice of breast cancer screening among Egyptian nurses. African Journal Of Haematology And Oncology. 2010;1(4). 
10. Obaji N, Elom H, Agwu U, Nwigwe C, Ezeonu P, Umeora O. Awareness and practice of breast self. Examination among market women in Abakaliki, South East Nigeria. Annals of medical and health sciences research. 2013;3(1):7-12.

11. Desanti OI, IM Sunarsih S. Persepsi Wanita Berisiko Kanker Payudara Tentang Pemeriksaan Payudara Sendiri Di Kota Semarang, Jawa Tengah. Berita Kedokteran Masyarakat. 2010;26(3):152.

12. Didarloo A, Nabilou B, Khalkhali HR. Psychosocial predictors of breast self-examination behavior among female students: an application of the health belief model using logistic regression. BMC public health. 2017;17(1):861.

13. Ergin AB, Sahin NH, Sahin FM, Yaban ZS, Acar Z, Bektas H. Meta analysis of studies about breast self examination between 2000-2009 in Turkey. Asian Pacific Journal of Cancer Prevention. 2012;13(7):3389-97.

14. Ahmed BaA. Awareness and practice of breast cancer and breast-self examination among university students in Yemen. Asian Pacific journal of cancer prevention: APJCP. 2010;11(1):101-5.

15. Al-Dubai SAR, Ganasegeran K, Alabsi AM, Manaf MRA, Ijaz S, Kassim S. Exploration of barriers to breast-self examination among urban women in Shah Alam, Malaysia: a cross sectional study. Asian Pacific Journal of Cancer Prevention. 2012;13(4):1627-32.

16. Apriliyana D, Agusyahbana F, Mawarni A, Nugroho D. Hubungan Persepsi, Paparan Media Informasi dan Dukungan Orang Tua Dengan Praktik Pemeriksaan Payudara Sendiri (Sadari) pada Remaja Putri Di SMA Negeri 3 Semarang Tahun 2017. Jurnal Kesehatan Masyarakat (e-Journal). 2017;5(4):207-14.

17. Barghouti FF, Yasein A, Takruri A, Hammouri T, Qasem N. Women's Knowledge and screening behaviors regarding breast cancer at family medicine clinics. International Medical Journal. 2013;20(1):59-63.

18. Pontoh F, Kairupan B, Sondakh J. Hubungan Antara Pengetahuan, Sikap Serta Dukungan Keluarga Dengan Tindakan Pemeriksaan Payudara Sendiri (Sadari) Pada Mahasiswi Semester Ii Akbid Makariwo Halmahera. Paradigma. 2018;5(2).

19. Ahmadian M, Samah AA. A literature review of factors influencing breast cancer screening in Asian countries. Life Sci J. 2012;9:585-94. 